
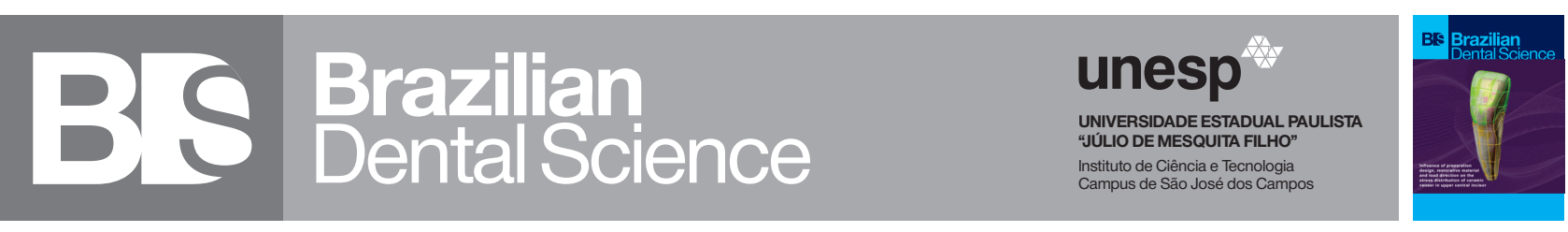

\title{
Split-Block Graft Versus Cortico-cancellous Block Graft for Horizontal Ridge Augmentation: Cone Beam Computed Tomography and Histomorphometric Study
}

Enxerto de bloco dividido versus enxerto de bloco córtico-esponjoso para aumento horizontal do rebordo: imagens de tomografia computadorizada de feixe cônico e estudo histomorfométrico

Mina A. BOTROS ${ }^{1}$, Hala K Abdel GABER ${ }^{2}$, Effat A ABBAS ${ }^{1}$, Mohamed S El-MOFTY ${ }^{2,3}$, Mohamed W BISSAR ${ }^{2}$

1 - Department of Basic Dental Science, National Research Center, Dokki, Giza, Egypt.

2 - Department of Oral Diagnosis, Periodontology and Diagnosis, Faculty of Dentistry, Ain Shams University, Cairo, Egypt.

3 - Faculty of Dentistry, Nahda University, Bani Sweif, Egypt.

\section{ABSTRACT}

Objective: The aim of this study was to compare the horizontal dimensional changes of split-bone block and cortico-cancellous block graft in horizontal ridge augmentation using Cone Beam Computed Tomography (CBCT). The quality of the regenerated bone in both groups was compared histologically and histomorphometrically. Material and methods: Twenty patients were randomly divided in two equal groups $(n=10)$ : Split-bone block group which was harvested from the external oblique ridge or cortico-cancellous block graft group which was harvested from the mandibular symphysis. Preaugmentation crestal ridge width was measured using bone caliper. CBCT scans were taken on the $2^{\text {n }} d$ week and $4^{\text {th }}$ month post-operatively to measure crestal and total horizontal ridge dimensions. A biopsy was collected from the regenerated ridge immediately before implant insertion on the $4^{\text {th }}$ month post-operatively. Results: Pre-augmentation crestal bone widths of both groups were comparable $(\mathrm{P}=0.870)$. On the $2^{\text {nd }}$ week and $4^{\text {th }}$ month postoperatively, split-bone block showed a significantly wider crestal $(\mathrm{P}=0.028$ and $\mathrm{P}=0.001$ respectively) and total horizontal ridge dimension $(\mathrm{P}=0.025$ and $\mathrm{P}=0.002$ respectively), and on the $4^{\text {th }}$ month postoperatively, it showed significantly lesser resorption at crest $(\mathrm{P}=0.040)$ and in total horizontal ridge dimension $(\mathrm{P}=0.017)$ than cortico-cancellous block. Histologically, the regenerated bone quality was similar in both groups. Histomorphometric analysis showed a non-significant difference in percentage of mature $(\mathrm{P}=0.365)$ and immature collagen $(\mathrm{P}=$ 0.531 ) between both groups. Conclusion: Splitbone block maintained a significantly wider ridge

\section{RESUMO}

Objetivo: O objetivo deste estudo foi comparar as mudanças dimensionais horizontais do enxerto de bloco ósseo dividido e do enxerto de bloco córtico-esponjoso no aumento de rebordo horizontal por meio da Tomografia computadorizada de feixe cônico (TCFC). A qualidade do osso regenerado em ambos os grupos foi comparada histológica e histomorfometricamente. Material e Métodos: Vinte pacientes foram divididos aleatoriamente em dois grupos iguais $(\mathrm{n}=10)$ : Grupo de blocos de osso dividido retirado da crista oblíqua externa ou Grupo de enxerto em bloco córtico-esponjoso retirado da sínfise mandibular. A largura da crista pré-aumentada foi medida usando calibrador ósseo. Os exames de TCFC foram realizados na segunda semana e quarto mês de pós operatório para medir as dimensões da crista e dimensões horizontais totais do rebordo. Uma biopsia foi coletada da crista regenerada imediatamente antes da inserção do implante no quarto mês pós-operatório. Resultados: As larguras do osso crestal pré-aumentado de ambos os grupos eram compatíveis $(\mathrm{p}=$ 0,870 ). Na segunda semana e quarto mês pós-operatórios, o bloco ósseo dividido mostrou uma crista significativamente mais larga ( $\mathrm{p}=0,28$ e $\mathrm{p}=0,001$ respectivamente) e a dimensão da crista horizontal total ( $\mathrm{p}=0,025$ e $\mathrm{p}=0,002$ respectivamente), enoquartomêspós-operatório, apresentou reabsorção significativamente menor na crista $(\mathrm{p}=0,040)$ e na dimensão da crista horizontal total $(p=0,017)$ em comparação ao bloco córtico-esponjoso. Histologicamente, a qualidade do osso regenerado foi semelhante em ambos os grupos. A análise histomorfométrica mostrou uma diferença não significativa na porcentagem de colágeno maduro (p $=0.365)$ e colágeno imaturo $(\mathrm{p}=0,531)$ entre ambos os grupos. Conclusão: O bloco ósseo dividido manteve uma crista significativamente mais larga e apresentou menos reabsorção após 4 meses, em comparação ao enxerto em 
and experienced less resorption after 4 months than the cortico-cancellous block graft, with no difference in regenerated bone quality between both groups.

\section{KEYWORDS}

Dental implants; CBCT; Cortico-cancellous block graft; Histomorphometric analysis; Split-bone block technique. bloco córtico-esponjoso, sem diferença na qualidade do osso regenerado entre ambos os grupos.

\section{PALAVRAS-CHAVE}

Implantes dentários; TCFC; Enxerto em bloco corticoesponjoso; Análise histomorfométrica; Técnica de bloqueio ósseo.

\section{INTRODUCTION}

A fter tooth loss, the alveolar ridge experiences an irreversible and progressive diminution in both width and height [1]. This may render implant placement impossible, or in an incorrect position both functionally and esthetically [2,3]. Therefore, multiple ridge augmentation protocols have been suggested in order to correct these defects.

Intramembranous autogenous osseous grafts have been considered as a reliable grafting material for the reconstruction of atrophied ridges as they combine all properties required in a bone graft material: osteoinduction, osteoconduction and osteogenesis [4]. The cortico-cancellous block grafts harvested from the mandibular symphysis provide mechanical support and rigidity of the cortical portion, and enhanced revascularization of the cancellous portion, thus ensuring adequate ridge augmentation [5]. On the other hand, block grafts harvested from the external oblique ridge are composed only of cortical bone, which take longer period for re-vascularization and remodeling, and may suffer sequestration years after augmentation [6].

Khoury \& Khoury [6] proposed the splitbone block technique using a combination of thin autogenous cortical plate and bone particles. This thin cortical plate is fixed at a distance from the atrophied ridge to act as an autogenous rigid membrane that offers stability to the underlying particulate autogenous bone, which has a high surface area that promotes osteoconduction. Additionally, this layer gives the ridge its shape and volume.
To the best of our knowledge, there are no available studies comparing the dimensional changes and bone quality of both split-bone block technique and cortico-cancellous block graft. For this reason, the aim of this study was to compare the horizontal dimensional changes of split-bone block and cortico-cancellous block graft in horizontal ridge augmentation using Cone Beam Computed Tomography (СBCT). The quality of the regenerated bone in both groups was compared histologically and histomorphometrically. The null hypothesis of this study was that both techniques would have the same effect on horizontal ridge augmentation and bone quality.

\section{MATERIAL AND METHODS}

Patients were selected from the outpatient clinic of Oral Medicine, Periodontology and Oral Diagnosis Department, Faculty of Dentistry, Ain Shams University. The protocol of this study was reviewed and approved by the ethical committee of the Faculty of Dentistry, Ain Shams University (FDASU - REC ID 021807). This study was conducted in accordance with the Helsinki Declaration of 1975, as revised in 2013. The surgical procedures and the post-operative complications such as infection, inflammation and swelling were explained in details to all patients and a signed informed consent was obtained.

\section{Eligibility criteria for the participants}

Patients in both sex with partial edentulism of the mandible and requiring horizontal ridge augmentation prior to implant placement were included in this study. The ages of the patients ranged from 18 to 50 years. The residual ridge 
width in these patients was $4 \mathrm{~mm}$ or less, and intra-oral donor sites were available in the external oblique ridge and symphyseal area. Patients with general contraindications for implant surgery such as uncontrolled diabetes mellitus, irradiation of the head and neck region, intravenous bisphosphonate, pregnancy, smokers, alcoholics and drug abusers were excluded from this study.

\section{Sample size calculation:}

Sample size calculation was conducted using G*Power 3.1.9.4 Software based on data obtained from a previous study [7]. The effect size was determined as 1.06. The power of t-test was set at $80 \%$ using a two-tailed significance level of $5 \%$, resulting in a sample size of 10 patients per group for a total of 20 patients.

\section{Treatment grouping}

Twenty patients were randomly divided in two equal groups $(n=10)$ by an internet softwaregenerated random numbers using the website www.randomlists.com. These two groups were Split-bone block group which was harvested from the external oblique ridge and Cortico-cancellous block graft group which was harvested from the mandibular symphysis.

\section{Pre-surgical preparation}

Panoramic radiographs were used during the selection of patients to evaluate the availability of both donor sites in each patient. Initial periodontal therapy, including scaling and root planing, was performed and oral hygiene measures were given to the patients. A radiographic stent was fabricated on the duplicate cast of the diagnostic wax-up using hard vacuum-formed thermoplastic matrix and guttapercha was placed into a notch on the center of the occlusal surface of the future implant [8]. The patients were given a prophylactic regimen of $2 \mathrm{~g}$ Amoxicillin/Clavulanic acid (Augmentin SmithKline Beecham, Philadelphia, PA) orally, or clindamycin 600 mg (Dalacin C, Pfizer, Auckland, New Zealand) orally, if they were allergic to penicillin, 1 hour before surgery.

\section{Surgical protocol}

All the surgeries were performed by the same operator. The patients were instructed to rinse for 1 minute with $0.2 \%$ Chlorhexidine solution (Hexitol 0.2\%, ADCO Pharma Co, Cairo, Egypt) immediately before the surgery. The surgical procedures were performed under local anesthesia (40 mg Articaine hydrochloride with epinephrine at 1:100.000, Inibsa Laboratories, Barcelona, Spain).

\section{Recipient site preparation}

At the recipient site, a full thickness flap was elevated and advancement was achieved at this stage. The width of the alveolar crest was measured with a caliper (Helmut Zepf Medizintechnik $\mathrm{GmbH}$, Seitingen-Oberflacht, Germany) $1 \mathrm{~mm}$ apical to the crest at the central position of the future implant as dictated by the radiographic stent (pre-augmentation width). Multiple decortication holes at the recipient site were performed with small round bur [9].

\section{Split-bone block harvesting}

The harvest of the split-bone block was performed according Khoury and Hanser [10] as shown in Figure (1a-f). With the aid of surgical carbide burs (HM 162) (Hager \& Meisinger $\mathrm{GmbH}$, Neuss, Germany), two proximal vertical cuts penetrating the cortex of the external oblique ridge were performed. The depth of penetration of the posterior cut did not exceed $2.5 \mathrm{~mm}$ to avoid injury to the inferior alveolar nerve. By using microsaw (Dentsply Sirona, Charlotte, NC, USA), an inferior cut of $3.2 \mathrm{~mm}$ in depth joining the anterior and posterior vertical cuts was done. Small perforations of $3-4 \mathrm{~mm}$ in depth were performed on the superior aspect of the external oblique ridge using $1 \mathrm{~mm}$ drill bur. Finally, the block was sheared off using a chisel. The harvested cortical plate was then split longitudinally in two parts using a microsaw, and thinned with the bone scraper (Osung USA, Pearland, Tx, USA) to achieve a plate of $1 \mathrm{~mm}$ thickness. The plate was fixed at a distance from the residual ridge with 2 screws (Devemed GmbH, Tuttlingen, Germany). Autogenous bone particles, collected with the bone scraper, were tightly packed into the gap between the plate and the recipient site. 


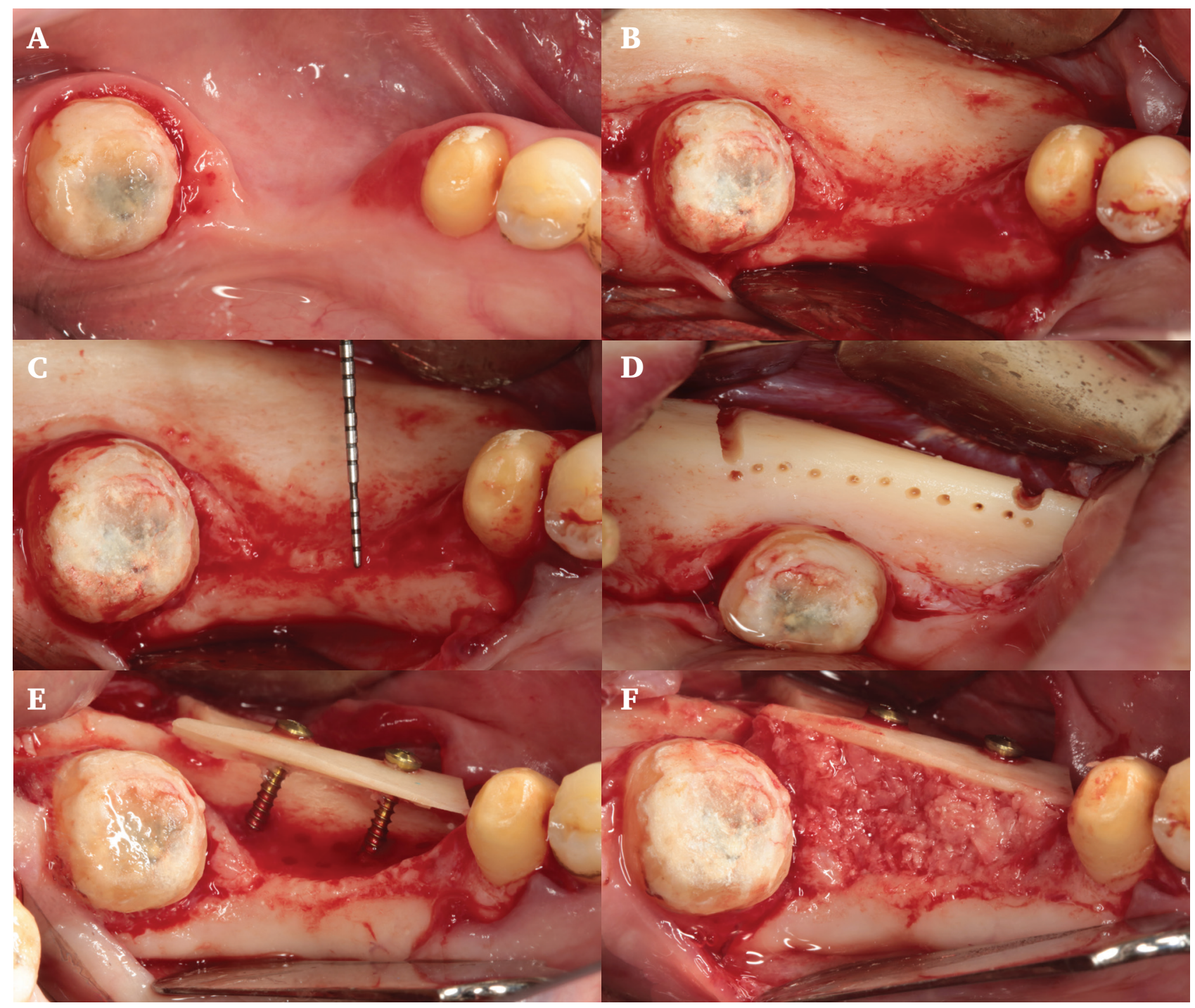

Figure 1 - A case treated with Split-bone block. (a) Preoperative occlusal view of the posterior mandibular edentulous thin ridge. (b) A thin residual ridge was evident after flap reflection. (c) The ridge crest measured $1 \mathrm{~mm}$ at its thinnest part. (d) The osteotomy to harvest the block from the external oblique ridge. (e) The plate was fixed at distance from the residual ridge leaving a gap. (f) Autogenous bone particles were tightly packed in the gap.

\section{Cortico-cancellous block graft harvesting}

A cortico-cancellous block graft was harvested from the symphysis area [11] as shown in Figure (2a-d). Respecting the rule of 5's, the desired size of the block was determined and notches were placed at the corners to outline the block. By using diamond discs (Helmut Zepf Medizintechnik GmbH, Seitingen-Oberflacht,
Germany), osteotomies penetrating the cortical layer to reach the underlying cancellous bone were performed. Once these cuts were made, chisel was used to shear the block off the underlying cancellous layer. The block was finally stabilized in place using 2 fixation screws. Autogenous bone chips were collected using bone scraper, and were used to fill any void between the block and the bed. 


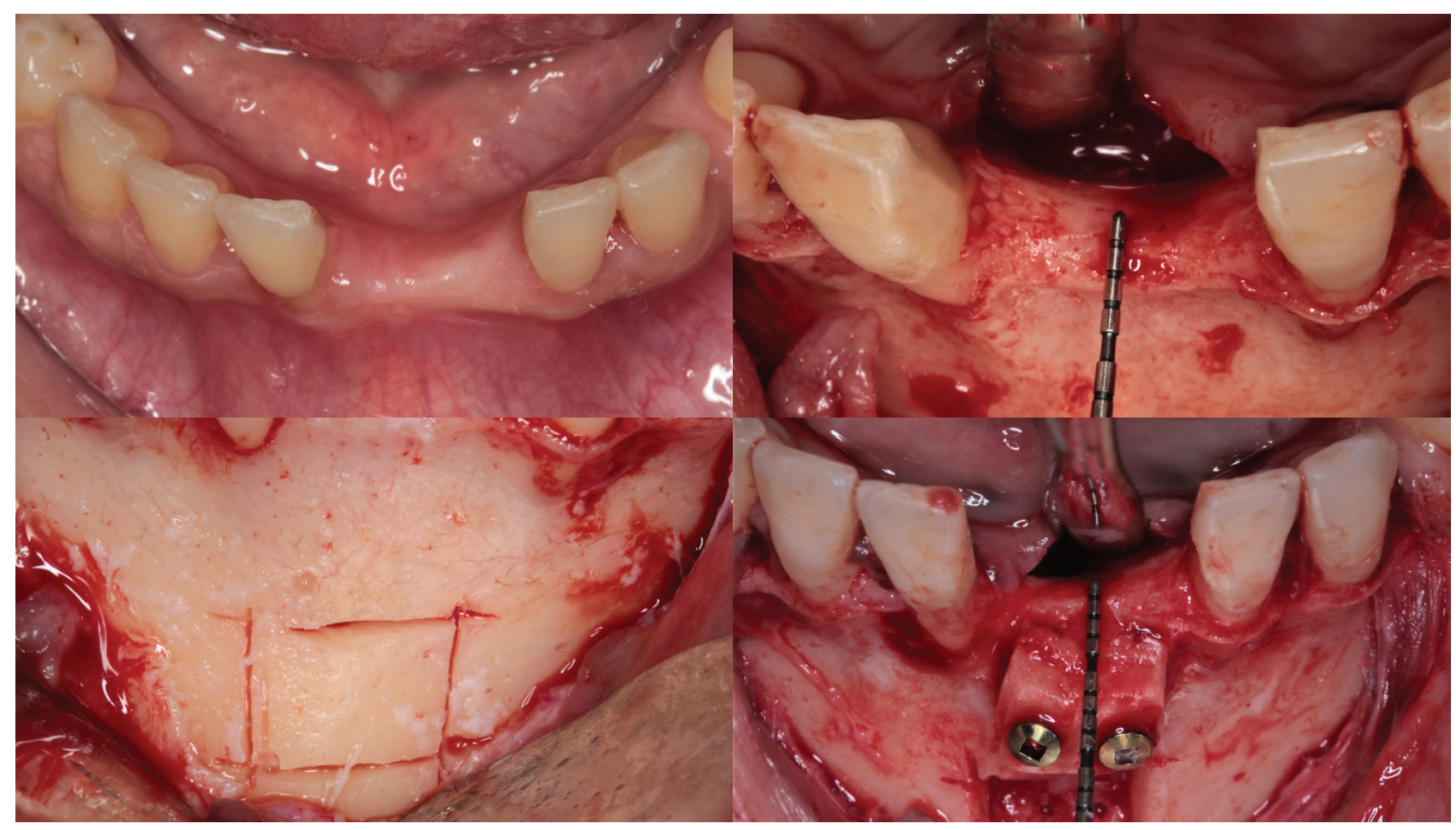

Figure 2 - A case treated with Cortico-cancellous block graft. (a) Preoperative occlusal view of the anterior mandibular edentulous ridge. (b) The ridge crest measured $2 \mathrm{~mm}$. (c) The osteotomy to harvest the block graft from the mandibular symphysis. (d) The block was fixed to the residual ridge.

In both groups, absorbable collagen sponge was placed on the donor sites. At the end of the surgery, tension free primary closure of the flaps was achieved. Horizontal mattress sutures were performed using 5-0 or 6-0 polypropylene suture which were followed by interrupted and continuous with lock sutures at coronal level. Post-operative medications were prescribed including Amoxicillin/Clavulanic acid $1 \mathrm{~g}$ orally every 12 hours for 7 days or Clindamycin $300 \mathrm{mg}$ orally every 8 hours for 5 days, Ibuprofen (Brufen by Abbott Laboratories, Abbott Park, North Chicago, IL, USA) $400 \mathrm{mg}$ orally every 6 hours for 5 days and $0.2 \%$ Chlorhexidine mouth rinse twice daily. Patients were instructed to refrain from removing plaque by mechanical means at the surgical sites for 2 weeks post- operatively. Sutures were removed 14 days post-operatively.

\section{Tomographic analysis}

The patients were instructed to wear the radiographic stent during each radiographic examination. On the $2^{\text {nd }}$ week and $4^{\text {th }}$ month postoperatively, a cone-beam computed tomography (CBCT) (iCAT Next Generation Cone Beam 3D system, Imaging Sciences International LLC, Hatfield, PA, USA) evaluation was used to measure crestal ridge and total horizontal ridge dimensions of the augmented bone. The imaging parameters were set at $5 \mathrm{~mA}, 120 \mathrm{KV}, 7$ seconds exposure time and voxel size of $0.2 \times 0.2 \times 0.2$ $\mathrm{mm}$. Using the i-CAT VisionTM inherent software (iCAT Vision version 1.9.3.13 by Imaging Sciences International LLC, Hatfield, PA, USA), a sagittal section at the center of the gutta percha placed on the radiographic stent was obtained throughout the examination process. Crestal ridge dimension of both groups was measured buccolingually at the most coronal point of the alveolar crest. The total horizontal dimension of the augmented ridge was measured buccolingually at 3 equidistant points perpendicular to the ridge, starting from the most coronal point of the alveolar crest to the apical extent of the graft. 


\section{analysis}

Histological and histomorphometric

They were used to evaluate the quality of regenerated bone. After a healing period of 4 months, a full thickness flap was raised in both groups (Figure 3a, b \& 4a, b) and fixation screws were removed. Bone core biopsy samples (approximately $2.5 \mathrm{~mm}$ in diameter and $8-10 \mathrm{~mm}$ in length) of the regenerated bone were then collected at the time of implant placement (Neobiotech Co., Ltd, Seoul, Korea) (Figure 5 \& 6) using a trephine bur (2.8 $\mathrm{mm}$ internal diameter), taking in consideration the 3D position of the implant. The core biopsy was immediately preserved in $10 \%$ buffered formaldehyde, then decalcified using a solution of $12 \%$ Ethylene diamine tetra-acetic acid (EDTA) buffered in pH 7.2 phosphate buffer saline (PBS) for three weeks at 4oC. Each specimen was dehydrated with ascending concentrations of alcohol (from 50\% to absolute alcohol) and finally embedded in a paraffin wax blocks. Each embedded specimen was sectioned along its longitudinal axis (5 $\mu \mathrm{m}$ thickness) using a microtome at 3 levels including the central part of the specimen to obtain a wide overview of the quality of the collected bone. The specimens were subjected to staining with Hematoxylin and Eosin stain (H\&E) for histological description, and Masson's trichrome special stain for histomorphometric analysis for the evaluation of the percentage of mature, immature and total collagen. The specimens were examined under normal light microscope (Olympus BX60, Olympus Optical Co., Ltd, Japan). The histomorphometric analysis was carried out using ImageJ software (National Institutes of Health, Bethesda, Maryland, USA).

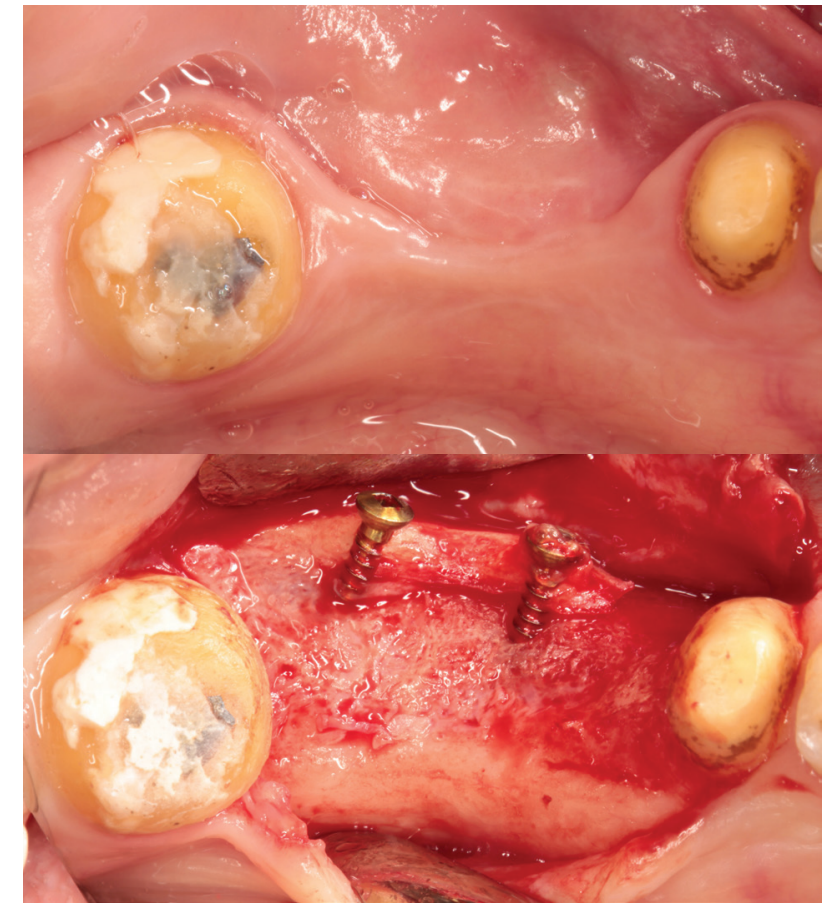

Figure 3 - Photograph showing the occlusal view of the regenerated ridge with split-bone block technique after 4 months: (a) before full thickness flap reflection. (b) after full thickness flap reflection.

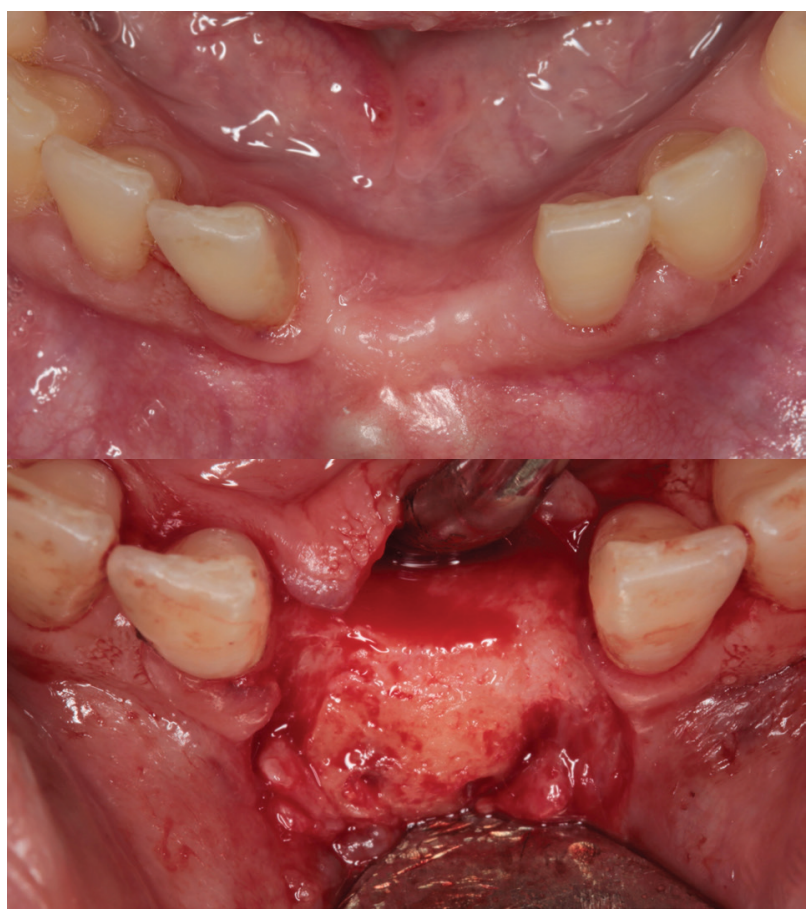

Figure 4 - Photograph showing the occlusal view of the regenerated ridge with cortico-cancellous block graft after 4 months: (a) before full thickness flap reflection. (b) after full thickness flap reflection. 


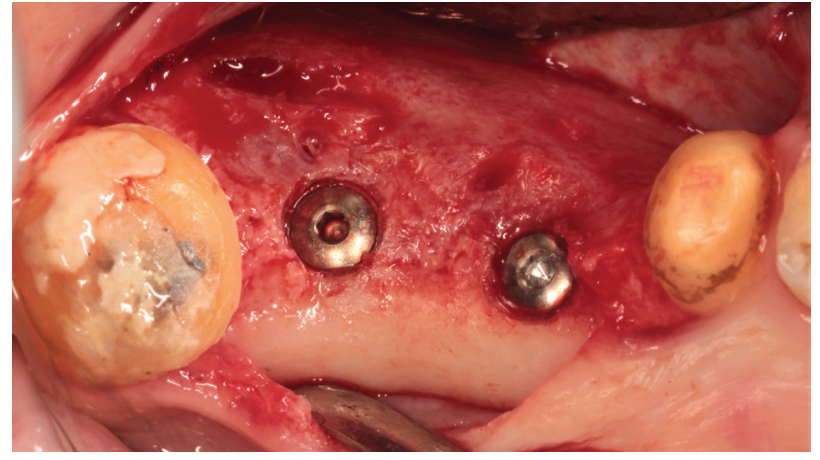

Figure 5 - Photograph showing the occlusal view of the implants installed in the regenerated ridge with split-bone block technique.

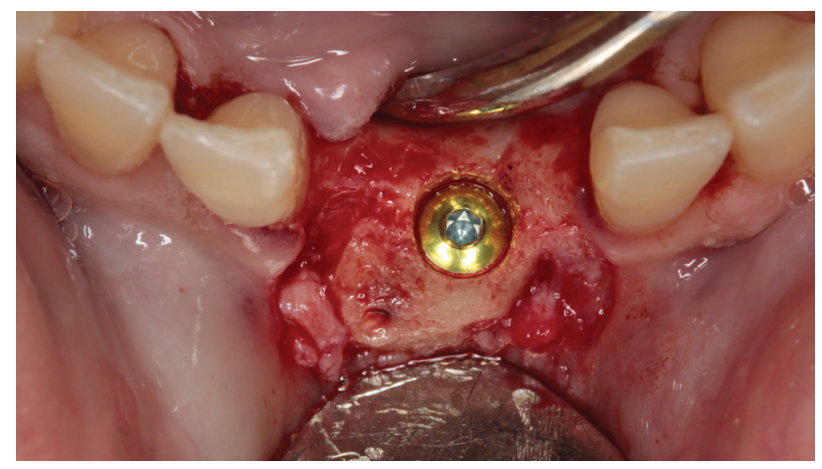

Figure 6 - Photograph showing the occlusal view of the implants installed in the regenerated ridge with corticocancellous block graft.

Statistical analysis was performed using IBM SPSS software for Windows (Version 2.1). Data was presented as Mean and Standard Deviation. The significance level was set at $\mathrm{P} \leq$ 0.05. Kolmogorov-Smirnov and Shapiro-Wilktests were used to assess data normality. Independent Student-t test was used for intra/inter-group comparisons of bone quality percentage, and intergroup comparisons of crestal width, total horizontal dimension of the augmented ridge and dimensional changes at each examination time. Within each group, Paired sample t-test was conducted to compare each of crestal width and total horizontal ridge dimension measured at the $2^{\text {nd }}$ week and $4^{\text {th }}$ month post-operatively.

\section{RESULTS}

A total of 12 female and 8 male patients with a mean age of 34 years old (range: 26 to 45 years old) participated in this study and they all attended the 4-month follow-up period. All augmented ridge healed uneventfully and allowed for implant placement.

The pre-augmentation mean width of the alveolar crest did not show any significant difference between split-bone block and corticocancellous block graft groups $(3.44 \pm 0.84 \mathrm{~mm}$ and $3.37 \pm 0.83 \mathrm{~mm}$ respectively, $\mathrm{P}=0.870$ ) (Table I).

On the 2nd week post-operatively, in comparison to the cortico-cancellous block graft, split-bone block showed a significantly wider mean crestal dimension $(7.18 \pm 1.27 \mathrm{~mm}$ and $8.68 \pm 1.42$ $\mathrm{mm}$ respectively, $\mathrm{P}=0.028$ ) and total horizontal dimension of the augmented ridge $(8.29 \pm 0.77$ $\mathrm{mm}$ and $9.87 \pm 1.77 \mathrm{~mm}$ respectively, $\mathrm{P}=0.025)$. On the $4^{\text {th }}$ month post-operatively, in comparison to the cortico-cancellous block graft, split-bone block exhibited a significantly wider mean crestal dimension $(5.17 \pm 1.02 \mathrm{~mm}$ and $7.96 \pm 1.73 \mathrm{~mm}$ respectively, $\mathrm{P}=0.01$ ) and total horizontal ridge dimension $(6.69 \pm 0.46 \mathrm{~mm}$ and $9.15 \pm 1.92 \mathrm{~mm}$ respectively, $\mathrm{P}=0.02$ ) (Figure $7 \mathrm{a}, \mathrm{b}$ and Table I). Crestal and total horizontal dimensions were significantly wider on the $2^{\text {nd }}$ week compared to the $4^{\text {th }}$ month post-operatively within split-bone block group $(\mathrm{P}=0.001$ and $\mathrm{P}=0.009$ respectively) and cortico-cancellous block graft group $(\mathrm{P}=<0.001$ and $\mathrm{P}=0.001$ respectively).

Table I - Crestal width and total horizontal dimension of the augmented ridge $(\mathrm{mm})$ of split-bone block and corticocancellous bock graft groups at different examination periods

\begin{tabular}{|c|c|c|c|c|c|c|}
\hline & \multicolumn{3}{|c|}{ Crestal width } & \multicolumn{3}{|c|}{$\begin{array}{c}\text { Total horizontal dimension of the } \\
\text { augmented ridge }\end{array}$} \\
\hline & $\begin{array}{l}\text { Split-bone } \\
\text { block group }\end{array}$ & $\begin{array}{c}\text { Cortico- } \\
\text { cancellous } \\
\text { block group }\end{array}$ & P-value & $\begin{array}{l}\text { Split-bone } \\
\text { block } \\
\text { group }\end{array}$ & $\begin{array}{c}\text { Cortico- } \\
\text { cancellous } \\
\text { block group }\end{array}$ & P-value \\
\hline $\begin{array}{l}\text { Pre-augmentation } \\
\text { width }\end{array}$ & $3.44 \pm 0.84$ & $3.37 \pm 0.83$ & 0.870 & & & \\
\hline $\begin{array}{c}2^{\text {nd }} \text { week } \\
\text { post-operatively }\end{array}$ & $8.68 \pm 1.42$ & $7.18 \pm 1.27$ & 0.028 & $9.87 \pm 1.77$ & $8.29 \pm 0.77$ & 0.025 \\
\hline $\begin{array}{c}4^{\text {th }} \text { month } \\
\text { post-operatively }\end{array}$ & $7.96 \pm 1.73$ & $5.17 \pm 1.02$ & 0.001 & $9.15 \pm 1.92$ & $6.69 \pm 0.46$ & 0.002 \\
\hline $\mathrm{P}$-value & 0.001 & 0.009 & & $<0.001$ & 0.001 & 0.025 \\
\hline
\end{tabular}

Data are expressed as mean \pm standard deviation.

Significant at $\mathrm{P} \leq 0.05$. 


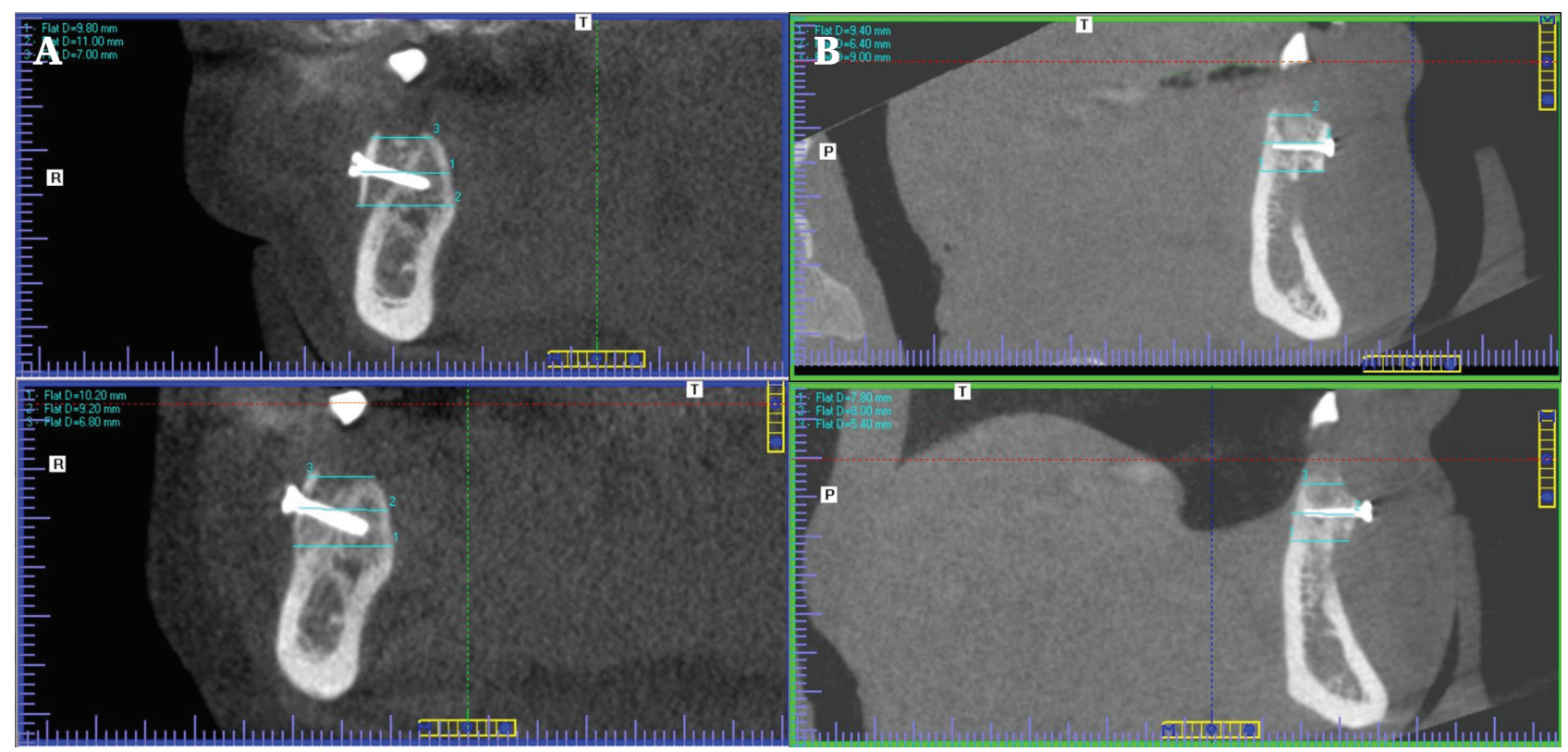

Figure 7 - Cone-beam computed tomography of the regenerated bone on the $2^{\text {nd }}$ week (top picture), and $4^{\text {th }}$ month (bottom picture): (a) Split-bone block. (b) Cortico-cancellous block graft.

In comparison to the split-bone block, cortico-cancellous block graft experienced a significantly higher horizontal crestal loss (- $0.72 \pm 0.47 \mathrm{~mm}$ and - $2.00 \pm 1.76 \mathrm{~mm}$ respectively, $\mathrm{P}=0.040$ ) and total horizontal ridge reduction $(-0.72 \pm 0.38 \mathrm{~mm}$ and $1.60 \pm 0.97 \mathrm{~mm}$ respectively, $\mathrm{P}=0.017$ ) at reentry (Table II).

Table II - Difference in crestal width and horizontal ridge dimension $(\mathrm{mm})$ of split-bone block and cortico-cancellous bock groups between the $2^{\text {nd }}$ week and $4^{\text {th }}$ month postoperatively

\begin{tabular}{|c|c|c|c|c|c|c|}
\hline & \multicolumn{3}{|c|}{ Crestal width } & \multicolumn{3}{|c|}{$\begin{array}{c}\text { Total horizontal dimension of the } \\
\text { augmented ridge }\end{array}$} \\
\hline & $\begin{array}{l}\text { Split-bone } \\
\text { block group }\end{array}$ & $\begin{array}{l}\text { Cortico- } \\
\text { cancellous } \\
\text { block group }\end{array}$ & P-value & $\begin{array}{l}\text { Split-bone } \\
\text { block } \\
\text { group }\end{array}$ & $\begin{array}{l}\text { Cortico- } \\
\text { cancellous } \\
\text { block group }\end{array}$ & P-value \\
\hline $\begin{array}{c}\text { Difference } \\
\text { between } 2^{\text {nd }} \text { week } \\
\text { and } 4^{\text {th }} \text { month }\end{array}$ & $-0.72 \pm 0.47$ & $-2.00 \pm 1.76$ & 0.040 & $-0.72 \pm 0.38$ & $-1.60 \pm 0.97$ & 0.017 \\
\hline
\end{tabular}

Data are expressed as mean \pm standard deviation Significant at $P \leq 0.05$.
The histological evaluation of bone specimens of split-bone block group (Figure 8a) showed intimate contact with multiple reversal lines demarcating the union between old and new bone. The new bone showed apparent large Haversian canals with large basophilic osteocytes. The new bone was also formed of irregular lamellae with large sized fibrocellular marrow cavities that were lined by osteoblasts. The bone specimen of the corticocancellous group (Figure $8 \mathrm{~b}$ ) showed obvious line of demarcation separating between old and new bone. The new bone showed apparent large Haversian canals with large basophilic osteocytes. The old bone showed well-formed Haversian system with apparent narrow Haversian canals and shrunken osteocytes. The new bone was formed of longitudinal lamellae with fibrocellular marrow cavities that lined by osteoblasts. Some H\&E samples showed small areas with empty lacunae. 


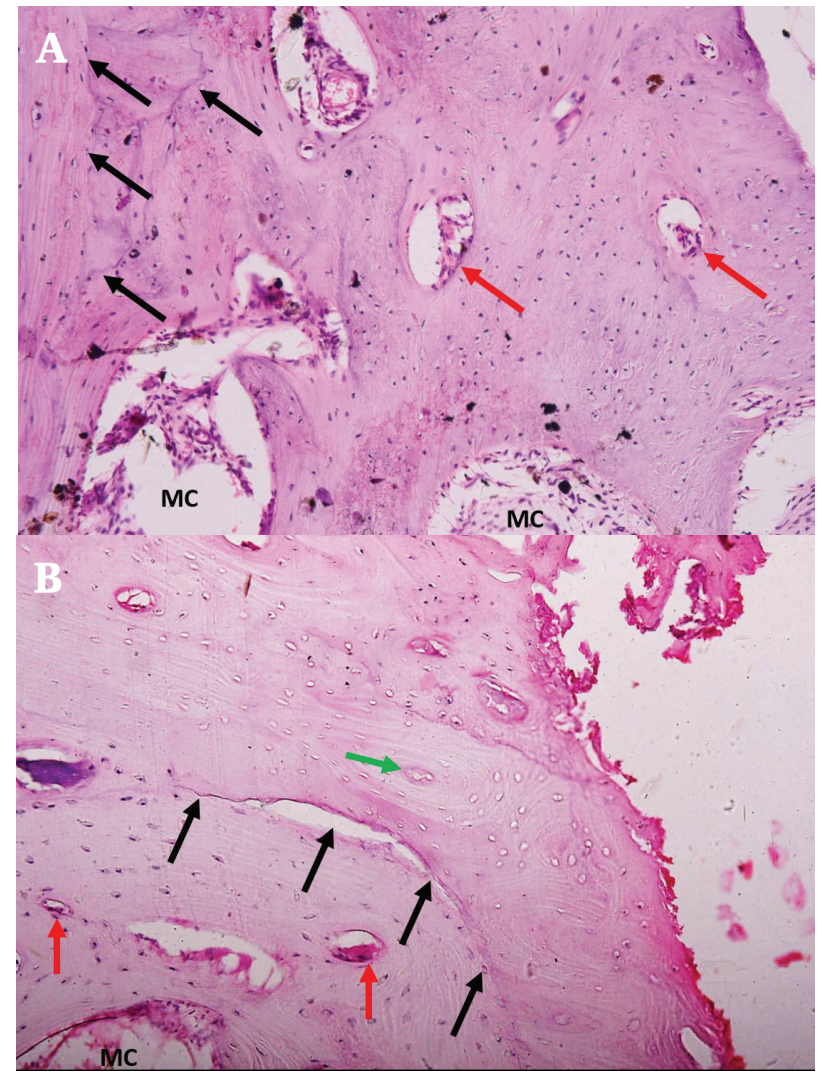

Figure 8 - A photomicrograph of the augmented ridge: (a) Split-bone block showing newly formed bone with multiple reversal lines (black arrows), large Haversian canals (red arrows), and large sized fibrocellular marrow cavities (MC) (H\&E, Original magnification X20). (b) Cortico-cancellous block showing newly formed bone separated from the old bone with reversal line (black arrows), large Haversian canals (Red arrows), old bone with narrow Haversian canals (Green arrow), and fibrocellular marrow cavities (MC) (H\&E, Original magnification X20).

The histomorphometric analysis showed that there were no statistically significant difference between split-bone block and corticocancellous block groups in percentage of mature collagen $(\mathrm{P}=0.365)$, immature collagen $(\mathrm{P}=$ $0.365)$ and total collagen $(\mathrm{P}=0.198)$. There was also no significant difference between percentage of mature and immature collagen within both split-bone block group $(\mathrm{P}=0.063)$ and cortico-cancellous block group $(\mathrm{P}=0.121)$ (Figure 9a, b and Table III).

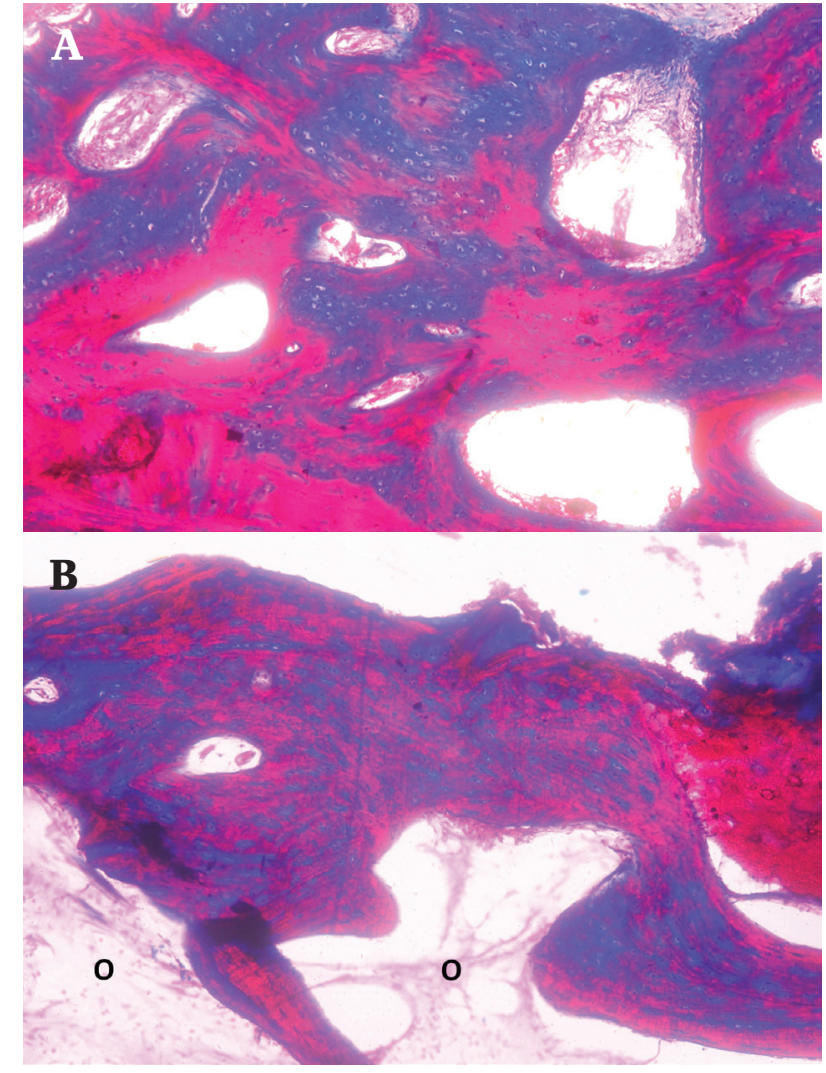

Figure 8 - A photomicrograph of the augmented ridge: (a) The split-bone block group showing bone filled with blue stained areas of immature collagen and red stained areas of mature collagen (Masson's trichrome stain, Original magnification X20). (b) Cortico-cancellous block showing intermingling blue and red areas and red stained areas of mature collagen with complete absence of blue color stained areas (O) (Masson's trichrome stain, Original magnification X20).

Table III - Histomorphometric analysis of split-bone block and cortico-cancellous bock groups.

\begin{tabular}{|cccc|}
\hline & $\begin{array}{c}\text { Split-bone } \\
\text { block group }\end{array}$ & $\begin{array}{c}\text { Cortico-cancel- } \\
\text { lous block group }\end{array}$ & P-value \\
\hline Total collagen (\%) & $40.56 \pm 13.25$ & $31.05 \pm 6.02$ & 0.198 \\
\hline Mature collagen (\%) & $15.15 \pm 8.78$ & $9.48 \pm 9.80$ & 0.365 \\
\hline Immature collagen (\%) & $25.40 \pm 5.34$ & $21.56 \pm 11.98$ & 0.531 \\
\hline P-value & 0.063 & 0.121 & \\
\hline
\end{tabular}

Data are expressed as mean \pm standard deviation Significant at $P \leq 0.05$. 


\section{DISCUSSION}

The split-bone block technique and the cortico-cancellous block graft exhibit different healing process, which may influence incorporation and resorption. For this reason, the aim of the present study was to compare these two techniques in terms of dimensional changes and bone quality after 4 months of healing.

The findings of the present study showed that split-bone block technique outperformed cortico-cancellous block graft in obtaining a thicker crestal and total horizontal ridge width 2 weeks post-operatively. This might be due to the flexibility offered by the split-bone block technique, which allowed fixation of the plate at the desired distance from the ridge. On the other hand, the mandibular symphysis exhibits a limited graft volume, due to the restricted anatomy of this region [11].

Although both grafts were harvested from the mandible and share the same embryological origin, they experienced different dimensional changes after 4 months. The split-bone block showed lesser resorption than the cortico-cancellous block graft. This might be due to the different healing process [6] and microarchitecture of both grafts [12]. Mandibular cortico-cancellous bone grafts possess the benefits of structural stability and osteoconductive medium from the cortical portion, and osteogenic potential and osteoinductive property from the cancellous portion [13]. The osteogenic potential of the graft comes from the survival of the grafted cellular elements [14]. However, newly formed bone from block grafts is mostly by osteoinduction and osteoconduction from the neighboring bone margins and much less through direct osteogenesis from surviving cellular elements. That is why onlay block grafts regenerate less bone and experience resorption [15] which begins in the most remote area of the graft from the native bone, because it is the last area to be reached with bone blood vessels, thus contains a high number of dead bone cells
[6]. Moreover, a dome-shaped appearance of the cortico-cancellous block graft was evident in our study at re-entry, which could indicate the resorption that occurred at the external surface. This finding came in accordance with a study conducted by $\mathrm{Oh}$ and his colleagues who related this pattern of resorption to the flap tension applied on the peripheral edges of the graft. This could have stimulated an osteoclastic activity resulting in a more pronounced resorption at the peripheries than at the central part, where the fixation screws relieved this tension [16]. The microarchitecture of autogenous bone block, which has an influence on block graft incorporation, maintenance and remodeling, has demonstrated that cortico-cancellous and cancellous autogenous block grafts experience significantly higher resorption than cortical autogenous bone blocks [12,17].

The vital advantage of the split-bone block technique, when compared to a block graft, is the regeneration of vital bone through osteoconduction, which contributes to more than $50 \%$ of the healing process [6]. Osteoconduction depends mainly on the amount of free graft surface in intimate contact with the underlying recipient bone. Increasing the total surface area of the grafted bone is beneficial for the regeneration of new bone. Thus, a one-piece block graft has a limited surface area when compared with particulate bone graft. Nevertheless, particulate bone grafts suffer from instability when used alone to reconstruct alveolar ridge defects [6]. Thus, Khoury and Khoury proposed the use of a thin cortical plate to act as an autogenous rigid barrier membrane that stabilizes the small bone particles. This thin cortical plate also provides the shape and form of the alveolar crest. These bone particles are characterized by superior revascularization and regeneration potential [10]. The lower resorption rate demonstrated in the split-bone block group of the present study could be attributed to the increased surface-tovolume ratio provided by the autogenous chips packed between the cortical bone plate and the recipient bone. By thinning the cortical bone plate, a larger room for autogenous chips was 
created to improve the graft's osteoconductive potential, revascularization and regeneration [18]. Autogenous bone chips also have an osteoinductive potential through the release of multiple proteins. Paracrine factors released from cortical bone include TGF- $\beta 1$ and 2, OSF1 and Gal-1 [19]. Thus, autogenous bone chips favored accelerated bone formation at early healing periods $[20,21]$.

Linear crestal width measurements were included in this study as crestal dimension has a direct effect on the marginal bone stability around the future implant [22]. Split-bone block showed lesser crestal bone resorption after 4 months than the cortico-cancellous block graft. The occurrence of bone graft resorption in the two groups of the present study was in agreement with some workers. De Stavola and Tunkel had recorded $0.25 \pm 0.29 \mathrm{~mm}$ crestal resorption after 4 months using the split-bone block for lateral ridge augmentation [23]. Stimmelmayr et al. reported a mean crestal loss of $0.8 \pm 0.5 \mathrm{~mm}$ after 4 month of healing [7]. Antoun et al. showed that ridges augmented with onlay graft harvested from the mandible symphysis experienced $2.3 \mathrm{~mm}$ resorption after 6 months [24].

In the present study, the findings of histological examination and histomorphometric analysis after 4 months revealed that the quality of the regenerated bone was similar in both groups. The histological examination showed that the interface between old and new bone was distinguishable. This was in disagreement with other studies [25-28]. This might be due to the direction of biopsy collection. In the present study, the core biopsy was taken from a crestal direction where the implant would be placed, to include both the original and augmented bone, while in the previous studies, it was retrieved perpendicularly from the lateral surface of the augmented bone [25-27]. In addition, some of H\&E samples of cortico-cancellous graft block group demonstrated small areas of empty lacunae. This is was in agreement with SpinNeto and colleagues [25]. The empty lacunae were due to the vanishing of osteocytes because of their entrapment in a mineral matrix and disruption of their fragile canalicular blood supply [15]. In addition, slower revascularization of the cortical portion of the cortico-cancellous block graft compared to the cancellous half of the block can be a contributing factor [2]. On the other hand, the multiple reversal lines and the large basophilic osteoblasts, seen in histological examination of both groups in this study, indicate the remodeling of the grafts. This is was in agreement with previous study [25].

In the present study, histomorphometric analysis showed a statistically similar percentage of mature and immature collagen as well as total bone collagen between both groups. Although the percentage of mature and immature collagen was insignificant within each group, the higher amount of immature collagen observed could signify the ongoing regeneration of the augmented ridge. Khoury and Khoury showed, through histological analysis, osteoid tissue in both cortical bone plate and mandibular block graft 4-month post-grafting [6].

The limitations of this study were the lack of long-term post-loading evaluation of marginal bone stability around implants and the absence of quantitative analysis of calcified tissue and mineral density which can provide an insight into graft site healing.

\section{CONCLUSION}

The split-bone block maintained a significantly wider ridge and experienced less resorption after 4 months than the corticocancellous block graft, with no difference in regenerated bone quality between both groups.

\section{Acknowledgment}

The authors reported no conflict of interest related to this study.

\section{REFERENCES}

1. Schropp L, Wenzel A, Kostopoulos L, Karring T. Bone healing and soft tissue contour changes following single-tooth extraction: a clinical and radiographic 12-month prospective study. Int J Periodontics Restorative Dent. 2003;23(4):313-23. 
2. Chappuis V, Cavusoglu Y, Buser D, von Arx T. Lateral ridge augmentation using autogenous block grafts and guided bone regeneration: a 10-year prospective case series study. Clin Oral Impl Res. 2016;19(1):85-96. doi:10.1111/ cid.12438.

3. Aloy-Prosper A, Penarrocha-Oltra D, Penarrocha-Diago M, PenarrochaDiago M. The outcome of intraoral onlay block bone grafts on alveolar ridge augmentations: a systematic review. Med Oral Patol Oral Cir Bucal. 2015;20(2):e251-8. doi: 10.4317/medoral.20194.

4. D'Addona A, Nowzari H. Intramembranous autogenous osseous transplants in aesthetic treatment of alveolar atrophy. Periodontol 2000. 2001;27(1):14861. doi: 10.1034/j.1600-0757.2001.027001148.x.

5. Fu JH, Wang $\mathrm{HL}$. Horizontal bone augmentation: the decision tree. Int $\mathrm{J}$ Periodontics Restorative Dent. 2011;31(4):429-36

6. Khoury F, Khoury CH. Mandibular bone block grafts: diagnosis, instrumentation, harvesting techniques and surgical procedures. In:Khoury F, Antoun, H, Missika P, editors. Bone Augmentation in Oral Implantology. Chicago: Quintessence; 2007:115-212.

7. Stimmelmayr M, Gernet W, Edelhoff D, Güth J, Happe A, Beuer F. Two-stage horizontal bone grafting with the modified shell technique for subsequent implant placement: a case series. Int J Periodontics Restorative Dent. 2014;34(2):269-76. doi: 10.11607/prd.1374.

8. D'Souza K, Aras M. Types of implant surgical guides in dentistry: a review. J Oral Implantol. 2012;38(5):643-52. doi: 10.1563/AAID-JOI-D-11-00018.

9. Proussaefs P, Lozada J. The use of intraorally harvested autogenous block grafts for vertical alveolar ridge augmentation: a human study. Int J Periodontics Restorative Dent. 2005;25(4):351-63

10. Khoury F, Hanser T.Mandibular bone block harvesting from the retromolar region: A 10-year prospective clinical study. Int J Oral Maxillofac Implants. 2015;30(3):688-97. doi: 10.11607/jomi.4117.

11. Pikos M. Mandibular block autografts for alveolar ridge augmentation. Atlas Oral Maxillofac Surg Clin North Am. 2005;13(2):91-107. doi: 10.1016/j. cxom.2005.05.003

12. Ozaki W. Buchman S. Volume maintenance of onlay bone grafts in the craniofacial skeleton: micro-architecture versus embryologic origin. Plast Reconstr Surg. 1998;102(2):291-9. doi: 10.1097/00006534-199808000-00001.

13. Myeroff C,Archdeacon M. Autogenous bone graft: donor sites and techniques. J Bone Joint Surg Am. 2011;93(23):2227-36. doi: 10.2106/ JBJS.J.01513

14. Nefussi JR. Bone biology and physiology of the implant bone site. In: Khoury F, Antoun H, Missika P, editors. Bone Augmentation in Oral Implantology. Chicago: Quintessence; 2007:1-27.

15. Marx R. Bone and bone graft healing. Oral Maxillofac Surg Clin North Am. 2007;19(4):455-66. doi: 10.1016/j.coms.2007.07.008.

16. Oh KC, Cha JK, Kim CS, Choi SH, Chai JK, Jung UW. The influence of perforating the autogenous block bone and the recipient bed in dogs, part I: a radiographic analysis. Clin Oral Implants Res. 2011;22(11):1298-302. doi: 10.1111/j.1600-0501.2010.02110.x.
17. Ozaki W, Buchman S, Goldstein S, Fyhrie D. A comparative analysis of the microarchitecture of cortical membranous and cortical endochondral onlay bone grafts in the craniofacial skeleton. Plast Reconstr Surg. 1999;104(1):13947.

18. Khoury F, Hanser T. Three-dimensional vertical alveolar ridge augmentation in the posterior maxilla: a 10-year clinical study. Int J Oral Maxillofac Implants. 2019;34(2):471-480. doi: 10.11607/jomi.6869.

19. Caballe-Serrano J, Bosshardt D, Buser D, Gruber R. Proteomic analysis of porcine bone-conditioned medium. Int J Oral Maxillofac Implants. 2014;29(5):1208-15. doi: 10.11607/jomi.3708.

20. Broggini N, Bosshardt DD, Jensen SS, Bornstein MM, Wang CC, Buser $D$. Bone healing around nanocrystalline hydroxyapatite, deproteinized bovine bone mineral, biphasic calcium phosphate, and autogenous bone in mandibular bone defects. J Biomed Mater Res B Appl Biomater. 2015;103(7):1478-87. doi: 10.1002/jbm.b.33319.

21. Janner S, Bosshardt D, Cochran D, Chappuis V, Huynh-Ba G, Jones A, Buser $D$. The influence of collagen membrane and autogenous bone chips on bone augmentation in the anterior maxilla: a preclinical study. Clin Oral Implants Res. 2017;28(11), 1368-80. doi: 10.1111/clr.12996.

22. Thoma DS, Maggetti I, Waller T, Hämmerle CHF, Jung RE. Clinical and patientreported outcomes of implants placed in autogenous bone grafts and implants placed in native bone: A case-control study with a follow-up of 5-16 years. Clin Oral Implants Res. 2019;30(3):242-251. doi: 10.1111/clr.13410.

23. De Stavola L, Tunkel J. A new approach to maintenance of regenerated autogenous bone volume: delayed relining with xenograft and resorbable membrane. Int J Oral Maxillofac Implants. 2013;28(4):1062-7. doi: 10.11607/ jomi.2726.

24. Antoun H, Sitbon JM, Martinez H, Missika P. A prospective randomized study comparing two techniques of bone augmentation: onlay graft alone or associated with a membrane. Clin Oral Implants Res. 2001;12(6):632-9. doi: 10.1034/j.1600-0501.2001.120612.x.

25. Spin-Neto R, Landazuri Del Barrio R., Pereira L, Marcantonio R, Marcantonio E,Marcantonio E Jr. Clinical similarities and histological diversity comparing fresh frozen onlay bone blocks allografts and autografts in human maxillary reconstruction. Clin Oral Impl Res. 2011;15(4):490-7. doi: 10.1111/j:17088208.2011.00382.x.

26. Spin-Neto R, Stavropoulos A, Coletti FL, Faeda RS, Pereira LAVD, Marcantonio E Jr. Graft incorporation and implant osseointegration following the use of autologous and fresh frozen allogeneic block bone grafts for lateral ridge augmentation. Clin Oral Impl Res. 2014;25(2):226-33. doi: 10.1111/clr.12107.

27. Spin-Neto R, Stavropoulos A, Coletti FL, Pereira LAVD, Marcantonio E, Wenzel A. Remodeling of cortical and corticocancellous fresh-frozen allogeneic block bone grafts: a radiographic and histomorphometric comparison to autologous bone grafts. Clin Oral Impl Res. 2015;26(7):747-52. doi: 101111/ clr.12343.

28. De Santis E, Lang NP,Favero G,Beolchini M, Morelli F, Botticelli D. Healing at mandibular block-grafted sites: an experimental study in dogs. Clin Oral Impl Res. 2015;26(5):516-22. doi: 10.1111/clr.12434.

\section{Mina A. Botros}

\section{(Corresponding address)}

Assistant Researcher, Department of Basic Dental Science, National Research Center, Dokki, Giza

Email: minabotros2410@hotmail.com

Date submitted: 2020 Aug 20

Accept submission: 2020 Sep 30 